Stefano Bianchini

\title{
The Tito-Stalin Split, the Italian Left and the Fascination with Anti-Stalinist Communism
}

When the Tito-Stalin split burst into the international arena in late June 1948, the variegated world of the Italian left was politically and ideologically unprepared to address the implications of such a traumatic event. Caught by surprise, its various players faced a double challenge: on the one hand, they had to comply with the complexity of the national and international geopolitical contexts; on the other, internally they had to tackle a largely unexpected heterogeneous multitude of reactions, which affected parties, militant affiliations, and the support of their constituencies.

\section{The dilemmas of the Italian Left on the eve of the Tito-Stalin split}

The Soviet-Yugoslav clash, in fact, occurred in a period when the borders between Italy and Yugoslavia were still unsettled due to the dispute about the future of the Free Territory of Trieste ${ }^{1}$. This was formally an independent territory, established on February 1947 according to the provisions of the Peace treaty with Italy. However, its self-government was never established. On the contrary, and despite the responsibility assigned to the UN Security Council, both states continued to claim their sovereignty over this strip of land and the city of Trieste, while the military administration of Zone A was under British and American control, and Zone B under that of the Yugoslav army. This situation was exacerbated by the growing tensions among the WW2 winners and, subsequently, by the beginning of the Cold War. With the obvious aim of influencing the results of the coming political elections in Italy, the governments of France, United Kingdom, and the US issued the so called "Tripartite declaration" on 20 March 1948,

1 The literature on the argument is really abundant. For a first approach see Dimitrijevic, Bitka za Trst, Wörsdörfer, Il confine orientale; Cattaruzza, L'Italia e il confine orientale; Valdevit, La questione di Trieste; Pacor, Confine orientale; Berce, Buducnost Trsta; Smodlaka, O razgraničenju Jugoslavije s Italijom. 
suggesting to the Soviet Union and Yugoslavia that the whole Free Territory of Trieste should be allowed to join Italy. ${ }^{2}$

These developments were particularly embarrassing for the Italian left and its Popular Democratic Front, whose main elements were the Communist and the Socialist parties, with the participation of the Republicans and other minor groups. Their unfavorable political position was determined by their internationalist inspirations, the complexity of the domestic situation, and the need to defend a patriotic position. Within this framework, they took a very critical view of the fascist legacy in Italy. At the same time, however, the dominant role of Yugoslavia in Istria put them at a crossroad between the loyalty to the "socialist brotherhood" and the preservation of national territories, which had been the focus of the "unredeemed Italy" narratives for decades. This was especially problematic when it came to the future of the cities of Trieste and Gorizia. Additionally, the balance between these two sentiments was affected by the confrontation between an escalating anti-communist hysteria and the widespread ardor manifested by leftist militants about the people's democracies which were being built. ${ }^{3}$

Meanwhile, other important events occurred in Italy before the Tito-Stalin split. They severely contributed to the increase in difficulties within the Italian Communist Party (ICP) at the time when the confrontation between Belgrade and Moscow reached its zenith. Firstly, after a successful result of the Popular Front in the Sicilian elections in April, Salvatore Giuliano, a criminal with strong political connections (from the neo-fascists to State officers and Italia-American Mafia families), perpetrated a murder of some leftist peasants at Portella della Ginestra ${ }^{4}$. A subsequent US intervention on the Prime Minister Alcide De Gasperi induced him to exclude both the Communist and Socialist parties from the government on 31 May 1947. Secondly, the ICP was uncompromisingly criticized during the first conference of the Cominform in Szklarska Poręba in September. During the meeting, as is known, the Yugoslav delegation, led by Edvard Kardelj and Milovan Đilas, expressed serious reservations about the parliamentary politics of the Italian and French Communists. In their view, they were implementing a "revisionist" attitude, which was not consistent with the revolutionary strategy of the international workers' movement. Rather, the two Yugoslav leaders invited the Italians to follow the example of the Greek Communist Party, which was fighting in the mountains against the military forces of the monarchy, at that time supported by the British army and, later, the US. As such approach was consistent with the political atmosphere

2 The most detailed diplomatic study about the Trieste controversy in Italy is still that of De Castro, La questione di Trieste, Additional documentation was analysed by Chicco, Trieste 1953 and Bianchini in I muteroli assetti balcanici, pp. 11-37.

3 Galeazzi (ed.), Roma-Belgrado; Pieluigi Pallante, Il PCI e la questione nazionale.

4 Orsatti's books Il bandito della guerra fredda, and Cassaburea, Storia segreta della Sicilia are based on recent declassified documents. 
of the conference produced by the Ždanov's report, the Italian delegation found itself in a very uneasy and frustrating position ${ }^{5}$.

Basically, in a few months, the ICP and its allies were on the one hand forced to quit the ruling coalition in Italy, while on the other, the strategy based on the rejection of an armed struggle, promoted by the general secretary Palmiro Togliatti, was put into question within the Cominform, that is, the newly established European Communist organization. These events generated intense repercussions, both in the Party's leadership and among the activists. Never monolithic, despite its official narrative, the ICP was stirring with different components and diversity of ideas. It was particularly among the former partisans, who actively took part in the war against the Nazi-fascists in the North of Italy between 1943 and 1945, that the attraction of revolutionary perspectives animated their expectations, passions, and a sentiment of nostalgia for the recent heroic times. Therefore, they demonstrated little enthusiasm for Togliatti's parliamentary strategy, which they viewed as too weak and, partially, also obsolete. Some of them even quit the Party between 1945 and 1946, believing it had betrayed the idea of national liberation. Others (the majority), who remained in its ranks, felt encouraged by the conclusions of the founding conference of the Cominform and claimed a more assertive policy against the government.

As a result, and despite the fact that Togliatti was (and remained) culturally very close to Stalin and the Soviet Union, his leading position in the Party gradually weakened over the year and, in late 1947 , his opinions soon represented only a minority within the executive committee. ${ }^{6}$ Still, according to typical communist practice, this decline remained confidential and no one publicly contested his role as the General Secretary of the Party. It was, therefore, under these circumstances that the ICP took part in the first free political elections of April 1948 with great confidence, together with its allies of the Popular Front. The outcome was, however, a harsh defeat, which came as a deep disappointment for the leftist parties. Subsequently, the pressure for a more aggressive social opposition strengthened within the ICP under the leadership of Pietro Secchia and Luigi Longo. ${ }^{7}$

It was exactly during this delicate period for the ICP that the world was informed about the Tito-Stalin split. Initially, the news was received with incredulity in Italy, as a temporary misunderstanding that would be soon overcome. In fact, both Stalin and Tito enjoyed great respect and prestige within the Italian left. The former was recognized as the undisputable leader of world communism, but the latter was appreciated as the triumphant partisan commander. True, the Yugoslav critique of the ICP delegation

5 Compare: Kardelj, Sećanja, pp. 108-110; Gilas, Se la memoria, pp. 152-154; Unkovski-Korica, The economic struggle, pp. 57-61 and Guerra, Gli anni del Cominform, pp. 153-156.

6 In Italy, this ambivalence of Togliatti's was negatively marked by the term "doppiezza" (which can be approximately translated as "double-dealing"). See Galeazzi, Togliatti e Tito, p. 103.

7 Collotti (ed.), Archivio Pietro Secchia, pp. 95-108. 
during the Cominform conference in Poland had a negative impact on the feelings of the leadership in Rome, but activists were mostly unaware that that had happened. As a result, in the weeks that followed the expulsion of Yugoslavia from the Cominform, the belief that room for mediation between the two parties still existed was predominant in the ranks of the Italian leftist public opinion.

Then on 14 July 1948, Togliatti was shot near the Parliament by an anticommunist student. Within a few hours, political tension in Italy reached its zenith and the country was on the verge of a civil war. Military forces were sent in to put down mass demonstrations and a general strike, and tens of people were killed or injured during street rallies. The tragedy was averted by Togliatti himself, who, speaking on the radio from his hospital bed after a successful surgical treatment, asked Longo, Secchia, and all activists to calm down and refrain from any irresponsible actions. His speech had beneficial effects because the uprising quickly subsided and the political atmosphere began to relax in the whole country. As a result, the news about the Tito-Stalin split did not attract a lot of attention because it was overshadowed by dramatic domestic events and national controversies, at least initially. By contrast, as soon as the situation became normalized, the issue began to acquire a different light under Cold War conditions.

The need to take sides in the confrontation between the two (East-West) camps was challenged by the new international role of Yugoslavia, which created new dilemmas. After all, this country was a people's democracy with a charismatic leader. Although excluded from the "communist brotherhood", Belgrade did not take any autonomous initiative thus far. On the contrary, its Fifth Congress held in July 1948 notoriously ended with paying an enthusiastic tribute to Stalin and the Soviet Union. At the same time, no relevant concessions were made by Tito to meet any demands made by the Kremlin. ${ }^{8}$

\section{The Italian Left facing the split}

Under these circumstances, the Italian left differentiated its reactions according to different pathways. Basically, at least four mainstream currents can be identified in this regard. The first one was embodied by the ideological and practical behavior of the ICP, carried out either formally or informally, depending on the different beliefs of its leaders. The second one was reflected in the variegated role that the press of the Popular Front played in the situation; the third one was epitomized by the conspiratorial actions of the "Stalinist hardliners", who were operating across Italy, the Free Territory of Trieste, and Yugoslavia; and the last one - probably the most original and interesting - was fascinated with the potential of an anti-Stalinist socialist perspective. The Yugoslav example, 
in fact, inspired a circle of respected former Italian partisans, together with people from the world of culture, to express unexpectedly critical statements about Soviet policies, generating mixed reactions in the ICP.

To begin with, the official party policy, and the Popular Front as a whole, took a public stance against the so-called "Titoist ideological deviation", in accordance with the Soviet instructions that were propagated by the Cominform. Nevertheless, even though the role played by the ICP was the most relevant and influential in the leftist domain, its leadership surprisingly adopted a mild attitude. Togliatti, in particular, recommended to Giuliano Pajetta, who was the ICP delegate to the Cominform, to "criticize, but also express appreciation of the Yugoslav comrades." Several reasons may have compelled Togliatti to take this ambivalent approach, but, regretfully, the minutes of the top deliberative body of the Party on the Soviet-Yugoslav affair after June 1948 were often left incomplete. Admittedly, however, the cautious conduct of the ICP in this period was mostly the result of their serious alarm about the risk of a new world war. For example, in his introductory report at the Regional Committee of Emilia-Romagna in March 1949, Antonio Roasio openly referred to the coalition led by De Gasperi as a "war cabinet". ${ }^{10}$ Within this framework, the Party concentrated its organizational efforts to promote a pro-Soviet peace movement, which proved to be particularly active in the 1940s and 1950s, pushing for intense public manifestations and persistent mobilization of activists and citizens. On the other hand, it cannot be excluded that Togliatti was trying to ensure a potential mediation role between Belgrade and Rome about the unsettled border issues for himself. Therefore, it might have seemed advisable to maintain a prudent position in what was still publicly presented as an ideological controversy between Tito and Stalin for potential inter-state diplomatic action.

Actually, this hope, if it ever existed, did not yield any results. But some expectations in this regard could have been held in Belgrade, since Mladen Iveković, the Yugoslav ambassador in Rome, expressed his disappointment with the lack of an intermediary attempt by the ICP in a telegram to his Ministry of Foreign Affairs on 25 March 1949.11 Whatever the case may have been, such a wait-and-see attitude of Togliatti's could also explain why the communist press maintained a similar "rear-guard position" towards Belgrade in this period, by occasionally publishing critical articles against Titoism. For example, the influential weekly Rinascita limited its contribution to an article by Felice Platone, who mentioned the "mistakes" and the "ideological betrayal" of the Yugoslav leadership who fell, in his view, into the trap of nationalism. However, Platone's real aim was to defend the ICP against the critique of the clerical "Civic Committees" and the social-democrat secessionists, who argued that the Italian Communists were confirming

9 Galeazzi, Togliatti fra Tito e Stalin, p. 108.

10 APC, FIG, Partito, 1949, MF 0301/1653.

11 Arhiv Kancelarije Maršala Jugoslavije I-3-B/336 reported by Galeazzi (ed.), Roma-Belgrado, p. 110. 
their loyalty to the "proletarian internationalism" and Moscow's guidelines, while setting aside the previously "heralded national character" of their political strategy. ${ }^{12}$ Even the daily newspaper l'Unità sporadically published short polemical texts against Belgrade, without going into detail about the social and economic situation in the country, which was basically ignored. By contrast, the socialist weekly Mondoperaio periodically published critical articles on the economic development of Yugoslavia, on international affairs, and on social and domestic policies, following the Cominform instructions with greater consistency. In a sense, reactions to the Tito-Stalin split expressed by the allies of the Italian Communists were, quite surprisingly, closer to Stalin than the leaders of the ICP and its press, whose attitudes remained basically tepid.

This also impacted the relations with Moscow, and particularly with the Italian section of the international office of the Central Committee of the CPSU, led by Dmitri Ševljagin, who expressed his disappointment behind the scenes, strengthening contacts mostly with his friend Pietro Secchia. The political atmosphere within the party leadership quickly became tense and dark. As a result, in the fall of 1949, when the Yugoslav government invited Italian partisans who had cooperated with the Yugoslav Army during the military operations after 1943 to take part in the celebration of the fifth anniversary of the liberation of Belgrade, the reaction of the ICP was excessive.

Under these circumstances, Giuliano Pajetta wrote a violent article in l'Unità against the invitation. ${ }^{13}$ Pajetta had long been considered a "suspicious element" in Moscow because of his prudent statements at the meetings of the Cominform and, even more, because of his warm friendship with Lászlo Rajk since the Spanish civil war. A few days later, the communist daily published a resolute letter by the Italian Association of Partisans (ANPI). The letter was signed by a number of influential Italians who struggled under Tito's Army, and whose content critically compared the "noble ideals of the liberation war" with the "tyrannical and fascist régime" that Tito had imposed on his country. ${ }^{14}$

Actually, this vehemence was just a temporary blaze, unusual for the ICP. It can be explained particularly by the growing pressure from the Kremlin, not satisfied with Togliatti's strategy. The suggestions that were coming from Moscow to the top bodies of the Party were encouraging a more assertive policy, either at the domestic or international level, with greater intensity of mass demonstrations and strikes. This was also the view frequently expressed by Secchia and some other leaders, sometimes publicly, but

12 Platone, Il fronte del socialismo e i casi di Jugoslavia, in "Rinascita", n. 7, lug. 1948, pp. 246-251.

13 G. Pajetta, Un inganno di Tito, in “''Unità", 14 oct. 1944, p. 1. See also his brother's book, GC. Pajetta, Le crisi che ho vissuto, pp. 86-88. Lászlo Rajk was a Hungarian minister of Interior who was arrested and shot in 1949 . He was accused by the Party's leader Rákosi of being a "Titoist”, although he was not. For details see Fejtö, Beyond the Rape.

14 I partigiani italiani respingono un invito di Tito, in "l'Unità", 20 oct. 1949, p. 1 with a comment by M. Kolenc (or Mario Colli, a communist leader from Trieste). 
more often during the restricted meetings of the leadership, whose decisions, however, leaked out selectively. In other words, a dispute about the future of the leadership was taking shape, albeit with great discretion.

\section{Clandestine movements in Istria and ICP hardliners}

By contrast, an uncompromised aggressive policy, both at the local level and particularly against Yugoslavia, was conducted by the Communists of the Free Territory of Trieste, led by the Stalinist Vittorio Vidali. The party regularly published vehement critical articles, either in the weekly Il Lavoratore or in booklets, against "Tito-fascism" or "Tito's clique", which were terms frequently used in Trieste. ${ }^{15}$ Vidali himself wrote the introduction to the party congress report by Karel Šiškovič-Mitko against "Tito-fascism"16. Notoriously, his leadership was autonomous from the ICP, although he maintained intense connections with hardliner leaders in Rome. Actually, his relations with the ICP were often troubled, so he rejoined the party only, and reluctantly, in 1957, that is three years after the signing of the London Memorandum, which allowed the incorporation of Trieste into the territory of the Italian republic ${ }^{17}$.

Although the controversial issue of the FTT goes beyond the limitations of this chapter, the abovementioned third mainstream had a conspiratorial base in Trieste and in the region of Istria. In fact, its geopolitical location played a crucial hinge role in the relationships along the line of Rome-Trieste-Belgrade. Particularly, activism promoted in this context by a group of Italian leftists made them, simultaneously, the protagonists and the victims of the conflict between Tito and Stalin.

The reference here is to a real immigration flow, which involved people from various Italian regions, who were highly politically motivated, and who moved mainly to Istria after World War II, and to a lesser extent to Belgrade, Sarajevo, and Ljubljana. After 1947, thousands of workers, especially from Monfalcone's shipyards, joined Pula and Rijeka's docks with the aim of "helping their Yugoslav comrades build socialism," where they offered their expertise for the reconstruction of the naval shipbuilding industry. At the same time, they were also a cohesive group of people, who easily established organized communities at the local level. When, therefore, the news of the Tito-Stalin split broke out, the initial disorientation quickly crystallized and a great majority of them expressed support for the thesis of the Cominform. As a result, when Alfredo Bonelli (a Stalinist hardliner, originally close to Secchia) arrived in Rijeka from Milan

15 See for instance: La banda di Tito, "Il Lavoratore", 22 Aug. 1949, p. 1; La Jugoslavia sotto il terrore, p. 105., translated from the original booklet of the Organe du bureau d'information des partis communistes et ouvriers, $L a$ Yougoslavie sous la terreur de la clique Tito, introd. by Duclos, Sedic-Sarl, Paris, 1949; Vidali, Sul Titismo, p. 64; Ezio Taddei, I crimini del Titismo, p. 31.

16 Vidali, "Prefazione" to Karel Šiškovič-Mitko, La lotta contro il titofascismo, p. 45.

17 Colli et al., Comunisti a Trieste. 
in November 1948, the local environment seemed to be favorable for establishing a clandestine movement inspired by the Cominform. And, in fact, an illegal organization led by Bonelli, together with Andrea Scano and Giovanni Pellizzari, began its activities in Rijeka in early $1949 .{ }^{18}$ Working mostly autonomously and with a voluntarist spirit, it specialized in Cominformist propaganda and furtive spreading of information about the economic and social situation in Yugoslavia abroad. However, its members were soon identified and arrested. Later, Bonelli was banished, and he returned to Italy, while Scano spent three years in the Goli Otok camp. ${ }^{19}$ Still, a second organization was soon promoted by Adriano Dal Pont, a teacher originally from Friuli, who re-structured the group with the financial support of the ICP in Rome by maintaining intense contacts with Secchia and Antonio Cicalini. The basic support of these organizations was provided by the Italian immigrant workers in Istria, although Dal Pont developed a network of contacts with other groups and individuals throughout Yugoslavia. Nevertheless, this activism was doomed not to last. The organization was disbanded by Udba (the Yugoslav Secret Service) in 1951. A public trial was held one year later. Dal Pont and his followers were sentenced to several years in prison, mainly in the Sremska Mitrovica prison. The last of their group were freed in $1956 .^{20}$

However, ICP's pro-Soviet cohesion before the Tito-Stalin split was far from consistent. Divided lines did not mark the distance only between hardliner supporters of Stalin and those loyal to the Kremlin, but still maintaining prudent connections. Actually, various members nurtured serious doubts about the rationale of the Cominform arguments. Some of them, like for example the famous poet Alfonso Gatto, who was working for the communist newspaper l'Unità, quitted both the periodical and the Party in 1951. Others preferred to remain in the shadows, waiting for better times. Others voiced their disagreement, which the party leadership did not expect, widening unconsciously the inherent dichotomy of the ICP strategy, mainly represented by Togliatti and Secchia.

\section{Valdo Magnani's dissent and Yugoslav politics}

The person who played a crucial role in these circumstances was one of the most promising young followers of Togliatti, Valdo Magnani. He was the cousin of Nilde Iotti, Togliatti's partner, and the secretary of the Party in Reggio Emilia, one of the strongest ICP branches in Italy. Magnani, an alumnus of the University of Bologna, had previously been an officer in the Italian army during the Yugoslav occupation. He was stationed in Slovenia, later in Montenegro, Dubrovnik, and Herzegovina, and he

18 See the memoires of Bonelli, Fra Stalin and Tito.

19 Bianchini, Zwischen Stalinismus und Antistalinismus, pp. 57-86.

20 More details in Scotti, Goli Otok. Ritorno all'Isola Calva, pp.17-49. 
learned the Croatian language. When Italy collapsed after 8 September 1943, he joined Tito's partisans and took part in their military operations. Then he became an activist of the "Garibaldi" division of the JNA and a speaker of the political school that the Communists organized for the soldiers and officers in Velimlje. On 12 March 1945 he returned to Italy where he started his career in the ranks of the ICP. In 1948, he was elected member of the Italian Parliament and regularly visited Nilde Iotti and Togliatti in their house in Rome.

All these details are important to frame his personality and political relevance in order to understand how shocking the impact of his declaration of 19 January 1951 was. That day, when he finished his introductory report for the local communist congress, he extracted a note from his pocket and explained his ideas about "national independence". In particular, he expressed his disagreement with the expectation that the socialist revolution can be achieved through foreign military intervention. On the contrary, he asserted that the Party should openly declare that, in case of military aggression, wherever it might come from, the Italian Communist would defend his national territory. ${ }^{21}$

Although he never mentioned Tito, he was immediately accused of "Titoism". Similarly, with the ferocious campaign that was conducted in other socialist countries against autonomous leaders not necessarily close to Tito's ideas (as for example Rajk in Hungary, Xoxe in Albania or Kostov in Bulgaria and, later, Slansky in Czechoslovakia and Gomulka in Poland), a violent reaction hit Magnani and a group of intellectuals who stood by him in Italy. A few days after he read his declaration, Magnani was expelled from the ICP and was accused of being paid by the Yugoslav government. A series of harsh accusations in this regard, labelling him as a "traitor", "sold out to the enemy," appeared in the leftist press (including the socialist and republican ones). Even a suspicious attempt of kidnapping occurred on 25 January. ${ }^{22}$ Meanwhile, a rigorous strategy of isolation was applied by the ICP in order to avoid any "contagion" of his ideas among the former partisans and the activists of the Party, as well as Magnani's family and his father.

At this point, the story develops in two main directions simultaneously: one concerns the hidden division within the ICP leadership, despite its formal unity; the other one pertains to the establishment of a new political party, founded by Valdo Magnani together with the former partisan and general Aldo Cucchi. The organization enjoyed formal support of Yugoslavia, which was in search of an international and anti-Stalinist

21 Magnani and Cucchi, Dichiarazioni, p. 16. The details about Magnani's political experience have been widely scrutinized by myself since 1988 when I had the opportunity to access to the Yugoslav archives in Belgrade, the ICP archives, Magnani's family archive and to meet all the protagonists of these events still alive, including the speaker of the Italian Parliament, Ms. Nilde Iotti. The results of this long research are published in Bianchini (ed.), Valdo Magnani e l'antistalinismo comunista.

Bianchini (ed.), Valdo Magnani, pp. 96-7. 
communist alternative. Intricate events marked, therefore, subsequent developments, in this case along the Rome-Belgrade-Moscow line.

In fact, when Magnani made his declaration, Togliatti was recovering from a brain operation in Moscow, after a car accident he had in Ivrea in late August 1950. During this period, the ICP was de facto under the leadership of Secchia and Longo. An attempt of ousting Togliatti from the role of the General Secretary of the Party followed in the subsequent weeks. According to a variety of rumors and a detailed analysis elaborated by scholars and journalists, ${ }^{23}$ it seems that a secret meeting of the Cominform occurred in Bucharest, most probably in 1950, and Edoardo D'Onofrio might have represented the ICP. During this meeting, the proposal to offer the leadership of the Cominform to Togliatti was taken into serious consideration, but the Italian leader, when informed of it, bitterly objected. Then, when he reluctantly accepted Stalin's invitation to spend some time in Moscow to recover, the Soviet pressure to replace Togliatti in Italy intensified. Stalin personally suggested that Togliatti should take the leadership of the Cominform. Meanwhile, Dmitri Ševljagin worked hard in Rome to convince the Direction of the Party to support the initiative. An ICP delegation went to Moscow twice to persuade Togliatti. A telegram from Rome was sent to Moscow to confirm that, unanimously, the Direction of the Party backed Stalin's idea.

Years later, Giorgio Amendola and Nilde Iotti contested the accuracy of the content of the telegram because the support was expressed by the majority of those present and not unanimously. ${ }^{24}$ This confirms how intolerant the political atmosphere within the Italian left was in those days.

In the end, however, Togliatti succeeded in returning to Italy, but Stalinist hardliners took the opportunity to rebuke him for the quality and the loyalty of his collaborators, citing Magnani as a negative example. In so doing, they also sought to weaken his authoritative role as a national figure and his idea of a "progressive democracy". Furthermore, they also argued against Togliatti's romantic relationship with the young Nilde Iotti, since he was separated from his wife. In short, an oppressive and culturally regressive Stalinist atmosphere was acutely affecting the Party's hierarchy and, consequently, its members. Although these feelings had already been affecting the Party for a long time, Magnani's public dissent indisputably aggravated such attitudes. In the end, partially confirming his loyalty to Stalin in spite of it all, and partially aware of his political weakness in the ICP leadership, Togliatti sarcastically condemned Magnani's words with one short sentence, without ever mentioning the event. As for Nilde Iotti,

23 So far no original documents about this meeting of the Cominform have been found. Most probably they were destroyed. Nevertheless, in France Lilly Marcou collected the testimonies of Jacques Duclos and Agnes Sávgári; in Italy, Miriam Mafai as well as Nilde Jotti, when I met her at the Italian Parliament, expressed a firm opinion that a fourth Cominform meeting took place. See more details in my edited book Valdo Magnani, p. 93.

24 Ibid., p. 97. 
she had refused to see her cousin for at least a decade. Even when Magnani re-joined the ICP in 1962, despite the persisting vigorous reluctance in the Party both at the local and national levels, their relationship never fully recovered.

At the same time, while hidden clashes were shaking the ICP leadership between January and February 1951, Magnani was contacted by the Yugoslav Embassy in Rome at the request of Leo Mates, the then deputy Minister of Foreign Affairs. ${ }^{25}$ Magnani's declaration and the sharp reaction by the ICP were, in fact, interpreted in Belgrade as an attractive opportunity to put an end to their ideological isolation, paving the way, instead, to new and more ambitious international projects. The Yugoslav ambassador in Rome, Mladen Iveković, carefully followed the events in Italy, regularly reporting to Belgrade. As a result, already in February 1951, Nikola Mandić, who had met Magnani during the war and had later become Tito's secretary, was sent to Rome by Aleksandar Ranković.

In a semi-secretive atmosphere, he met Magnani in his house and learned about his project of creating a New Leftist party with an anti-Stalinist socialist orientation. At the end of their meeting, Mandić gave a financial donation to Magnani’s "Movement of the Italian Workers" (MIW). ${ }^{26}$ Other payments followed, although the amount gradually decreased as soon as it was obvious that the new party was unable to attract relevant support, particularly from the membership of the ICP who, despite individual hesitancies, remained loyal to its Party instead.

The relationship between Magnani and the Yugoslav leadership was, however, politically intense, at least until 1956. The MIW's marginal electoral results in 1953, despite Yugoslav financial support, significantly contributed to De Gasperi's defeat in his attempt to change the electoral law, while in 1955, after an initiative promoted in Slovenia by Boris Krajger and Miha Marinko in the aftermath of the implementation of the London Memorandum, the Yugoslav socialist component of the former FTT merged with Magnani's movement, who had in the meanwhile changed its name to the Union of the Italian Socialists (UIS). ${ }^{27}$

All these events, their implications for the internal harmony within the ICP and between the ICP and the Communists of Trieste, in addition to the never absorbed legacy of the 1951 declaration, affected the process of rapprochement between the YLC and the ICP in the mid-1950s. For example, when a prominent Italian leader, Giancarlo Pajetta, visited Belgrade on 3 December 1955, he made it clear to Veljko Vlahović and Anton Vratuša that Yugoslav support to Magnani was obstructing the improvement of their bilateral relations. ${ }^{28}$

25 Arhiv SSIP 91236,8-6, also in Bianchini, Valdo Magnani, p. 117.

26 I had personally the chance to discuss these issues with Nikola Mandić in Belgrade in 1989. The documentation is currently available in the Magnani archive at the Istituto Gramsci Emilia Romagna in Bologna. See, again, Bianchini, Valdo Magnani, p. 51 and p. 121.

27 Krajger and Marinko, Stenografski zapiski, pp. 266-285; Bianchini, Valdo Magnani, pp. 143-146.

28 Bianchini, Valdo Magnani, p. 151. 
On the other hand, however, Magnani's dissent was perceived in Yugoslavia as a serious opportunity to build up an anti-Stalinist but still communist movement in Europe. Some months earlier, on 28 June 1950, a similar project was considered during a meeting of the Communist Politburo, when the Minister of Foreign Affairs, Edvard Kardelj, elaborated the thesis according to which potential conditions existed for encouraging anti-Stalinist mass movements in Germany, France and Italy. He suggested, therefore, to avoid sectarian attitudes and look at socialist parties through new lenses. As Tito recommended to keep away from any temptation to re-create a new "Center of Command", a committee consisting of Ranković, Đilas and Vukmanović - Tempo was tasked with analyzing the situation and preparing a report. ${ }^{29}$ Subsequently, Đilas, in particular, was active in strengthening contacts with the British Labor Party, the French Socialists, and other social-democrats that might have an interest to initiate some forms of co-operation. In these circumstances, the embassy in Rome cautiously contacted former partisans in Yugoslavia or people who had expressed some doubts about the Cominform statements. Magnani was invited in July 1950, following a public manifestation in Naples when he mentioned the Yugoslav liberation war with comments that were judged as "objective" by the Embassy. Subsequently, his friend Nikola Mandić visited him in Reggio Emilia in the fall of 1950. The available documentation about these meetings, including the collected testimonies and minutes preserved in the Italian archives, confirm that these events were only opportunities for exchanging ideas, without any substantial political impact. ${ }^{30}$

At the same time, however, such clandestine communication networks illustrate well the atmosphere of uncertainty, feelings, and hopes that marked the broader international context, where semi-secret opinions circulated with great circumspection even in the Western world, crossing the Italian-Yugoslav borders unexpectedly easy for the time of the Cold War. It was, therefore, in these conditions that Magnani's declaration of 1951 acquired inflammatory relevance by unwittingly impacting the internal divisions within the ICP about the future of Togliatti's leadership, while in Belgrade it was enthusiastically welcomed as a confirmation that Yugoslavia was not alone in its idea that an anti-Stalinist communist alternative might really be established.

\section{Conclusions: the decline of a potential socialist convergence against the Cominform}

Despite the efforts that Belgrade had poured into this political experiment led by Magnani since February 1951 with the aim of helping it grow, the results were

29 Arhiv Jugoslavije-Fond CKSKJ, AR3/49, 28 June 1950 in Ibid., p. 79 and Bekić, Jugoslavija u bladnom ratu, p. 267. Kardelj returned to this issue in 1951, see also Arhiv CK KPJ/IX, 1-II/168, mar. 1951.

30 Nikola Mandić talked to me about this meeting. Magnani himself reported in Memoria sul MLI, now in Fond VM, FGR, Bologna. Bianchini, Valdo Magnani, p. 84. 
ultimately disappointing. Over time, it had become clear that it was not in the variety of the European leftist orientations that the Yugoslav resistance to Stalinist pressures could find substantial support. New events would contribute to modifications in the development of Cold War relations, particularly in the Balkans, from the Balkan Pact to the effects of destalinization, from Berlin mass protests to the Hungarian revolution, to such an extent that Yugoslavia was induced to look for new international opportunities outside Europe.

In the end, they were identified in the strategy of creating a Non-Aligned Movement, which gradually attracted world admiration to Tito and the Yugoslav federation. But the socialist content of the anti-Stalinist inspiration, so dear to Yugoslav leaders during the years that followed the split with Moscow, never acquired a substantial international role, with the limited exceptions of the Eurocommunist policy, nurtured under the Berlinguer leadership in Italy in the 1970s, and Gorbachev's reforms, to a large extent inspired by the Yugoslav self-management, particularly after his long visit to the country in 1988.

\section{Sources and literature}

\section{Archival sources}

Archivio PC, FIG Fondazione Istituto Gramsci, Roma, Partito, 1949, MF 0301/1653.

Archivio VM (Valdo Magnani), FGER (Fondazione Gramsci Emilia-Romagna), serie "Il ritorno nel PCI", b.5.1. fasc. 1 "Memoria sul MLI e sull'USP".

Arhiv SSIP 91236,8-6.

Arhiv CK KPJ/IX, 1-II/168, March 1951.

Arhiv Jugoslavije-Fond CK SKJ, AR3/49, 28 June 1950.

Arhiv Kancelarije Maršala Jugoslavije I-3-B/336.

\section{Newspapers (bold)}

L'Unita

Il Lavoratore

Rinascita

Slobodna Dalmacija

\section{Monographs}

Bekić, Darko, Jugoslavija u bladnom ratu. Zagreb: Globus, 1988.

Berce, Lojze, Budućnost Trsta u svetlu njegove prošlosti. Beograd: Piščevo, 1946.

Bianchini, Stefano (ed.), Valdo Magnani e l'antistalinismo comunista. Milano: Unicopli, 2013.

Bonelli, Alfredo, Fra Stalin and Tito. Cominformisti a Fiume 1948-1956, with the preface of Francesco Privitera. Trieste: Istituto regionale per la storia del movimento di liberazione del Friuli Venezia Giulia, 1994. 
Cassaburea, Giuseppe, Storia segreta della Sicilia. Dallo sbarco alleato a Portella della Ginestra. Milano: Bompiani, 2005.

Cattaruzza, Marina, L'Italia e il confine orientale. Bologna: Il Mulino, 2007.

Chicco, Gianni, Trieste 1953 nei rapporti USA. Trieste: ed. Italo-Svevo, 1993.

Colli, Mario et al., Comunisti a Trieste. Un’identità difficile. Roma: Editori Riuniti, 1983.

Collotti, Enzo (ed.), Archivio Pietro Secchia 1945-1973. Milano: Feltrinelli, 1979.

De Castro, Diego, La questione di Trieste. Trieste: Lint, 2 vol., 1982.

Dimitrijevic, Bojan, Bitka za Trst 1945-1954. Zagreb: Despot Infinitus, 2014.

Fejtö, François, Beyond the Rape of Hungary. New York: McKay, 1957.

Galeazzi, Marco (ed.), Roma-Belgrado. Gli anni della guerra fredda. Ravenna: Longo, 1995.

Galeazzi, Marco, Togliatti e Tito tra identità nazionale e internazionalismo. Roma: Carocci, 2005.

Gilas, Milovan, Se la memoria non m’inganna. Bologna: I1 Mulino.

Guerra, Adriano, Gli anni del Cominform. Milano; Mazzotta, 1977.

Kardelj, Edvard, Sećanja. Beograd: Radnička Štampa, 1980.

Magnani, Valdo and Aldo Cucchi, Dichiarazioni e documenti. Bologna: Tip. Luigi Parma, 1951.

Organe du bureau d'information des partis communistes et ouvriers, La Yougoslavie sous la terreur de la clique Tito. Introd. by Jacques Duclos, Paris: Sedic-Sarl, 1949.

Orsatti, Pietro, Il bandito della guerra fredda. Reggio Emilia: Imprimatur, 2017.

Pacor, Mario, Confine orientale. Milano: Feltrinelli, 1964.

Pajetta, Giancarlo, Le crisi che ho vissuto. Roma: Editori Riuniti, 1982.

Pallante, Pierluigi, Il PCI e la questione nazionale Friuli-Venezia-Giulia 1941-1945. Udine: Del Bianco, 1980.

Vkongres Komunisticke Partije Jugoslavije, Beograd: Kultura, 1948.

Scotti, Giacomo, Goli Otok. Ritorno all'Isola Calva. Trieste: Lint, 1991.

Unkovski-Korica, Vladimir, The economic struggle for power in Tito's Yugoslavia. London: Tauris, 2016.

Valdevit, Gianpaolo, La questione di Trieste 1941-1954. Milano: Angeli, 1987.

Vidali, Vittorio, Sul Titismo. Trieste: Riva, 1950.

Vidali,Vittorio, "Prefazione" to Karel Šiškovič-Mitko, La lotta contro il titofascismo. Trieste: ed. Il Lavoratore, 12 Feb. 1951.

Wörsdörfer, Rolf, Il confine orientale. Italia e Jugoslavia dal 1915 al 1955. Bologna: I1 Mulino, 2009.

\section{Articles}

Bianchini, Stefano, I mutevoli assetti balcanici e la contesa italo-jugoslava (1948-1956). Marco Galeazzi (ed.), Roma-Belgrado. Gli anni della guerra fredda. Ravenna: Longo, 1995.

Bianchini, Stefano, Zwischen Stalinismus und Antistalinismus. Säuberungen und politische Prozesse in Jugoslawien in den Jahren 1948 bis 1954. Maderthaner, Schafranek, Unfried (eds.), Ich habe den Tod verdient. Wien: Verlag für Gesellschaftskritik, 1991.

La Jugoslavia sotto il terrore di Tito, Milano: Edizioni di cultura sociale, 25 Dec. 1949.

Krajger, Boris and Miha Marinko, Stenografski zapiski. Zaliv n. 3-4, 1980, pp. 266-285. 


\section{Summary}

\section{Stefano Bianchini}

\section{The Tito-Stalin Split, the Italian Left and the Fascination with Anti-Stalinist Communism}

The contribution will focus on the impact of the Tito-Stalin split on the Italian Left. As is known, the reactions were diversified. On the one hand there was the position of the Italian Communist and Socialist Parties who supported Stalin mostly through media, although minor groups tried to support in Istria a secret movement of "resistance" against Tito. But more surprising for the time being was the process that started some years later, in 1951, when a closest collaborator of Togliatti, Valdo Magnani, took a public political position in support of communist autonomy from Moscow. Excluded from his party, he established a new anti-Stalinist movement, close to Tito, that divided the Italian Left and encouraged Yugoslavia to dream that a communist anti-Stalinist movement could rise in Western Europe. Although this hope vanished soon, the event had a great psychological impact on the Yugoslav leadership. 